\title{
Association of angiopoietin-2, C-reactive protein and markers of obesity and insulin resistance with survival outcome in colorectal cancer
}

\author{
E Volkova', JA Willis², JE Wells ${ }^{3}$, BA Robinson',4, GU Dachs' and MJ Currie*,I \\ 'Angiogenesis and Cancer Research Group, Department of Pathology, University of Otago Christchurch, PO Box 4345, Christchurch 8I 40, New Zealand; \\ ${ }^{2}$ Lipid and Diabetes Research Group, Christchurch Hospital, PO Box 4710, Christchurch 81 40, New Zealand; ${ }^{3}$ Department of Public Health and General \\ Practice, University of Otago Christchurch, PO Box 4345, Christchurch 8I 40, New Zealand; ${ }^{4}$ Oncology Services, Christchurch Hospital, PO Box 47 I0, \\ Christchurch 8140, New Zealand
}

BACKGROUND: This study investigated the relationship of obesity, insulin resistance, inflammation and angiogenesis with cancer progression and survival in a colorectal cancer cohort.

METHODS: Clinical and pathological data, along with anthropometric and follow-up data, were collected from 344 consecutive colorectal cancer patients. Serum samples at diagnosis were analysed by immunoassay for adiponectin, C-reactive protein (CRP), vascular endothelial growth factor-A (VEGF-A), angiopoietin-2 (Ang-2), insulin-like growth factor-I (IGF-I), insulin and C-peptide. RESULTS: Serum Ang-2 and VEGF-A levels increased with tumour T stage $(P=0.007$ and $P=0.025$, respectively) and $N$ stage $(P=0.02$ and $P=0.03$, respectively), and correlated with CRP levels $(r=0.43, P<0.00 \mathrm{I}$ and $r=0.23, \quad P<0.00 \mathrm{I}$, respectively). Angiopoietin-2 correlated with C-peptide $(r=0.14, P=0.007)$ and VEGF-A with IGF-I in males $(r=0.25, P=0.00 I)$. KaplanMeier analysis showed that patients with high serum levels of CRP and Ang-2 had significantly reduced survival (both $P \leqslant 0.00 \mathrm{I}$ ). After adjusting for tumour stage and age, Ang-2 remained a significant predictor of survival. The CRP levels were inversely associated with survival in American Joint Committee on Cancer stage II patients $(P=0.038)$, suggesting that CRP could be used to support treatment decisions in this subgroup. Serum markers and anthropometric measures of obesity correlated with each other, but not with survival. CONCLUSION: Our study supports the concept that obesity-related inflammation, rather than obesity itself, is associated with colorectal cancer progression and survival. The study confirms serum Ang-2 as a predictive marker for outcome of colorectal cancer.

British Journal of Cancer (20II) I 04, 5I -59. doi:I0.1038/sj.bjc.6606005 www.bjcancer.com

Published online 16 November 2010

(c) 201 I Cancer Research UK

Keywords: obesity; insulin resistance; tumour angiogenesis; angiopoietin-2; C-reactive protein

Colorectal cancer is the third most common cancer in women and the fourth most common cancer in men worldwide (Parkin et al, 2005). It is second only to lung cancer as a cause of cancer deaths in New Zealand (Frizelle, 2009), and New Zealand women have both the highest incidence and highest mortality from colorectal cancer in the world (Center et al, 2009).

Epidemiological studies have shown that the risk for colorectal cancer development is strongly related to obesity and the metabolic syndrome (Moghaddam et al, 2007; Pais et al, 2009). The mechanism underlying this association is not completely understood, but obesity-induced insulin resistance, adipokine levels and obesity-related inflammation are all important factors (Sandhu et al, 2002; Giovannucci, 2007; Birmingham et al, 2009; Gonullu et al, 2009), implicating insulin resistance and alterations in the insulin - insulin-like growth factor-1 (IGF-1) axis as the main driving forces (Komninou et al, 2003; Giovannucci, 2007).

*Correspondence: Dr MJ Currie; E-mail: margaret.currie@otago.ac.nz Received 28 July 2010; revised 22 October 20 0; accepted 22 October 2010 ; published online 16 November 2010
Both insulin and IGF-1 are potent mitogens that promote colorectal cancer cell growth and survival in vitro (Komninou et al, 2003), and elevated blood levels of IGF-1 and insulin are associated with increased risk of developing colorectal cancer (Komninou et al, 2003).

Angiogenesis, the formation of new blood vessels, has a vital function in tumour growth and spread (Rmali et al, 2006), and IGF-1 and insulin induce angiogenesis in vitro and in vivo (Reinmuth et al, 2002). Levels of the main angiogenic factors, vascular endothelial growth factor-A (VEGF-A) (Cao et al, 2009) and angiopoietin-2 (Ang-2) (Chung et al, 2006), are correlated with tumour progression and patient outcome in colorectal cancer.

Despite support for the importance of obesity and metabolic syndrome as risk factors for colorectal cancer development, data are equivocal for their effects on colorectal cancer progression and outcome (Trevisan et al, 2001; Dignam et al, 2006; Reeves et al, 2007; Meyerhardt et al, 2008; Moon et al, 2008; Wolpin et al, 2009). Several studies found worse survival and increased recurrence for patients with insulin resistance or high body mass index (BMI) (Trevisan et al, 2001; Dignam et al, 2006; Moon et al, 2008; Wolpin et al, 2009), while other studies reported no significant relationship 
(Meyerhardt et al, 2003; Reeves et al, 2007). Obesity influences duration of surgery and post-surgery complications in colorectal cancer patients (Tsujinaka et al, 2008; Merkow et al, 2009), and alters the response of breast cancer patients to chemotherapy (Litton et al, 2008).

In this study, we investigated the relationship of obesity, insulin resistance and inflammation with colorectal cancer progression and survival in a New Zealand colorectal cancer cohort. We propose that obesity-related chronic hyperinsulinemia and insulin resistance promote a pro-inflammatory and pro-angiogenic environment that stimulates tumour growth and metastasis, and leads to poor survival.

\section{MATERIALS AND METHODS}

\section{Patients}

The study cohort comprised consecutive patients undergoing surgery for adenocarcinoma of the colon or upper rectum at Christchurch Hospital between 28 July 1998 and 28 April 2008. All participants had given written informed consent for collection of tumour tissue and blood for research, and samples were obtained after approval from the Cancer Society Tissue Bank (CSTB), Christchurch. The study was approved by the Upper South Ethics Committee (approval number: URB/08/02/006). Stage IV patients $(n=14)$ were included, but were highly selected in having low volume metastatic disease, or undergoing colectomy at the time of emergency presentation with obstruction or perforation. All analyses were performed both with this group of stage IV patients included and excluded, and as results were similar, data are presented with stage IV patients included.

Patients were treated according to standard guidelines with preoperative staging by blood tests for full blood count, liver function tests, chest X-ray and computerised tomography of abdomen and pelvis. In a few cases, the liver was imaged by ultrasound or magnetic resonance imaging (MRI). Patients with rectal cancer also underwent MRI of the pelvis, but were then excluded from this study if they were treated with pre-operative radiation with or without concurrent chemotherapy. The surgical specimens were analysed pathologically by a specialist group of pathologists, although synoptic reporting was only formally introduced in 2005. Staging was by American Joint Committee on Cancer (AJCC) TNM classification (Greene et al, 2002). Post-operative adjuvant chemotherapy was offered to patients with nodes involved and also to node-negative patients with adverse features including perforation, vascular or lymphatic invasion and T4 tumours. Either intravenous weekly 5-fluorouracil with leucovorin, or capecitabine, or an oxaliplatin combination was administered. Patients were followed up routinely by the colorectal service at Christchurch Hospital with 6-monthly clinical assessment and blood carcinoembryonic antigen (CEA), with an annual and then 3-yearly colonoscopy, with imaging when indicated on clinical grounds or by CEA rise.

\section{Sample collection and storage}

Blood samples were collected into plain tubes (BD-vacutainer, Franklin Lakes, NJ, USA) from patients on admission to Christchurch Hospital, before colectomy. Blood samples were centrifuged (1800 r.p.m. $\times 10 \mathrm{~min}$ ), and the serum aliquoted and stored at $-80^{\circ} \mathrm{C}$ until used in immunoassays.

\section{Immunoassays}

Commercially available Quantikine human ELISA kits (R\&D systems, Minneapolis, MN, USA) for adiponectin, high sensitivity-C-reactive protein (CRP), VEGF-A, Ang-2 and IGF-1 and human ELISA kit (Millipore, Billerica, MA, USA) for insulin and $\mathrm{C}$-peptide were used to measure the levels of proteins in patient serum samples. All ELISAs were performed following manufacturers' protocols, with samples assayed in duplicate with appropriate standards as controls.

\section{Data collection}

Demographic and clinical data, along with the pathology report for each patient, were prospectively recorded in the CSTB database. Baseline staging, weight, height, body surface area and BMI were obtained from medical records, together with follow-up information. The BMI was defined as is standard with $<18.5 \mathrm{~kg} \mathrm{~m}^{-2}$ underweight; $18.5-24 \mathrm{~kg} \mathrm{~m}^{-2}$ normal; $25-29 \mathrm{~kg} \mathrm{~m}^{-2}$ overweight; $\geqslant 30 \mathrm{~kg} \mathrm{~m}^{-2}$ obese and $\geqslant 35 \mathrm{~kg} \mathrm{~m}^{-2}$ morbidly obese. Diabetes was recorded from the clinical records, but in addition blood glucose levels were checked to disclose previously undiagnosed type 2 diabetes. Follow-up was recorded until 31 August 2009.

\section{Statistical analysis}

Statistical analysis was performed using SPSS version 16 (SPSS Inc., Chicago, IL, USA, 16). Frequency and descriptive statistics were used to describe the cohort. Pearson's product-moment correlations were used to analyse relationships among serum markers, and between serum markers and tumour size, depth and percentage of bowel circumference. Independent-sample $t$-tests were used to compare the levels of serum markers in patients with or without diabetes, lymphatic and vascular invasion, perineural invasion, necrosis or lymph nodes metastasis. Oneway analysis of variance and linear test for trend were used to compare the levels of serum markers across tumour stages and grade. Both Kaplan-Meier and Cox regression analyses were performed to analyse patient overall survival. Medians were used to divide continuous data into groups for Kaplan-Meier analysis, with standard cut points for BMI. In Cox regression analysis, tumour stage was analysed as a categorical variable, and age, BMI and serum markers as continuous variables. For the continuous variables, hazard ratios were estimated using the following units: 100 units of VEGF-1, 1000 units of Ang-2, 1 unit of CRP, insulin, C-peptide and BMI, 10 units of IGF-1 and per decade of age. Predictors were entered either on their own, or jointly; stepwise procedures were not used.

\section{RESULTS}

\section{Colorectal cancer patients}

The study cohort of 344 patients included 173 males and 171 females. Individuals ranged in age from 31 to 91 years of age (mean $=71$, median $=73$ ) with $66 \%$ of patients aged between 60 and 80 years (Table 1). Only six females were $<50$ years of age, hence assumed pre-menopausal. Twenty per cent were AJCC stage I, $42 \%$ AJCC stage II, 34\% stage III and $4 \%$ stage IV. Vascular or lymphatic invasion was identified in 101 out of 337 tumours $(30 \%)$ and perineural invasion in 17 out of 159 tumours (11\%), where these were recorded. Twenty-eight individuals $(8.1 \%)$ had a diagnosis of type 2 diabetes mellitus.

The BMI decreased with advancing age, with no difference by gender (Table 2 ). Only $2.2 \%$ of patients were underweight, with $27.7 \%$ normal weight, $45 \%$ overweight and $25.1 \%$ obese including $6.9 \%$ morbidly obese. This distribution reflects the background New Zealand population (Ministry of Health, 2008).

\section{Clinicopathological and serum factors}

Serum levels of the angiogenic factors VEGF-A and Ang-2, and the inflammatory factor CRP, according to clinicopathological features are shown in Table 1. Data for the metabolic factors adiponectin, IGF-1, insulin and C-peptide are available in Table 2. 
Table I Serum angiogenic and inflammatory factors according to clinicopathological features in colorectal cancer patients

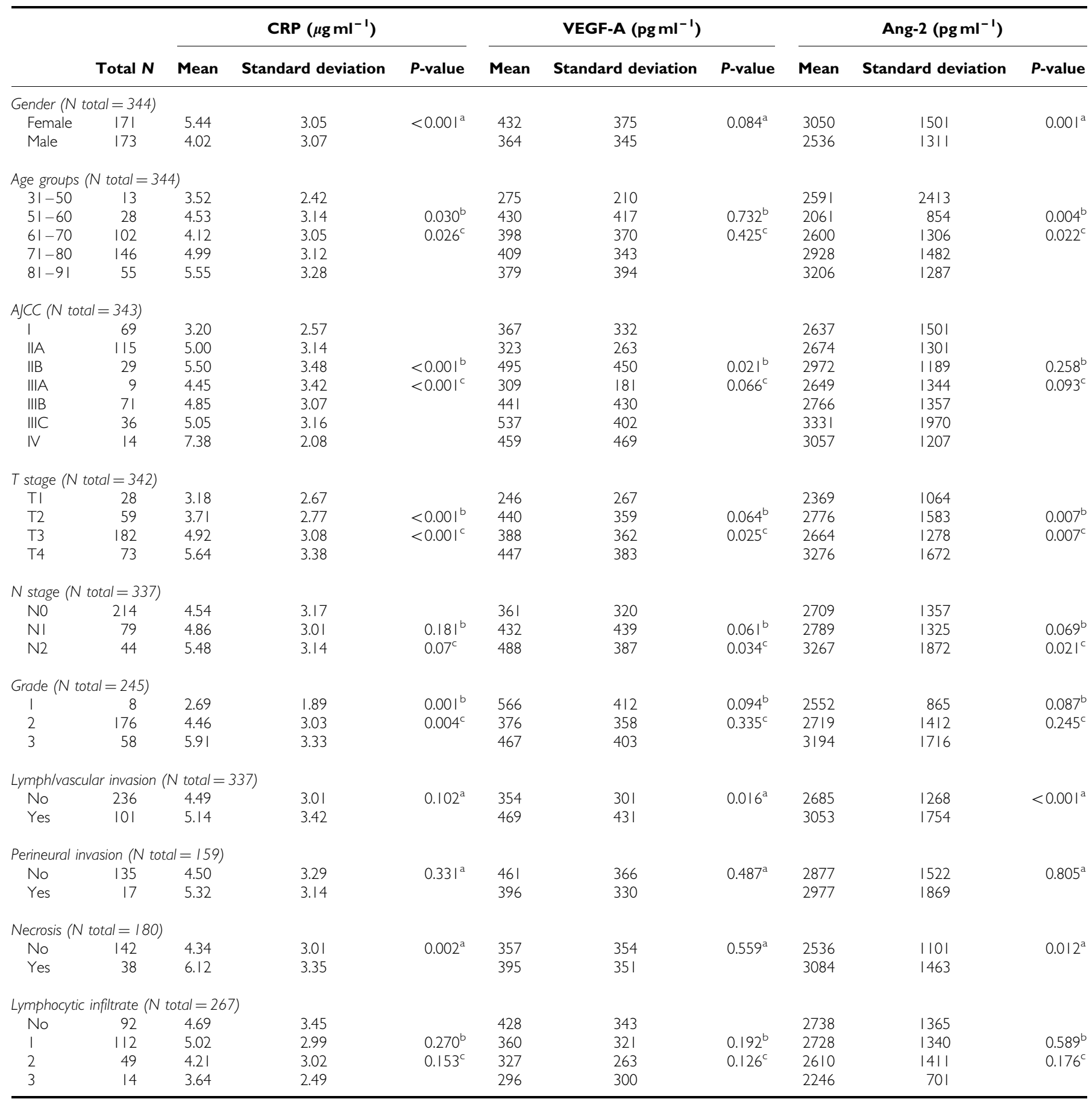

Abbreviations: $\mathrm{AJCC}=$ American Joint Committee on Cancer; Ang-2 = angiopoietin-2; ANOVA = analysis of variance; $C R P=C$-reactive protein; VEGF- $=$ vascular endothelial growth factor-A. aIndependent-samples $t$-test. ${ }^{b}$ One-way ANOVA. ${ }^{\top}$ Test for linear trend.

The VEGF-A levels were significantly higher at more advanced $\mathrm{T}$ (tumour) stage $(P=0.025)$ and $\mathrm{N}$ (nodal) stage $(P=0.034)$, but not AJCC stage $(P=0.07)$, as well as when lymphatic and vascular invasion was present $(P=0.02)$. Angiopoietin-2 levels increased with age $(P=0.02)$, more advanced T stage $(P=0.007)$ and $\mathrm{N}$ stage $(P=0.02)$, but did not significantly correlate with AJCC stage $(P=0.09)$. Angiopoietin-2 levels were higher when tumour necrosis was present $(P=0.01)$, but necrosis data was missing in $48 \%$ of cases. The CRP levels increased with tumour AJCC stage $(P<0.001)$, T stage $(P<0.001)$ and higher grade $(P=0.004)$, as well as with increased tumour necrosis $(P=0.002)$. Levels of Ang-2 and
CRP were significantly higher in women compared with men $(P=0.001$ and $P<0.001$, respectively). Adiponectin levels increased with age $(P=0.005)$, were higher in the absence of perineural invasion $(P=0.03)$, although data were not available for all patients. Adiponectin levels were higher in women $(P<0.001)$ and IGF-1 levels were higher in men $(P<0.001)$.

\section{Surrogate markers of obesity}

The anthropometric measure BMI was positively correlated with serum levels of insulin $(r=0.21, P<0.001)$ and C-peptide $(r=0.27$, 
Table 2 Obesity-related factors according to clinicopathological features in colorectal cancers patients

\begin{tabular}{|c|c|c|c|c|c|c|c|c|c|c|c|c|c|c|c|c|}
\hline & \multirow[b]{2}{*}{$\begin{array}{c}\text { Total } \\
\mathbf{N}\end{array}$} & \multicolumn{3}{|c|}{ Adiponectin (ng ml ${ }^{-1}$ ) } & \multicolumn{3}{|c|}{ IGF-I (ng mI- $)$} & \multicolumn{3}{|c|}{ Insulin $\left(\mu \mathrm{U} \mathrm{ml}^{-1}\right)$} & \multicolumn{3}{|c|}{ C-peptide $\left(\mu \mathrm{g} \mathrm{ml}^{-1}\right)$} & \multicolumn{3}{|c|}{ BMI } \\
\hline & & Mean & $\begin{array}{l}\text { Standard } \\
\text { deviation }\end{array}$ & $P$-value & Mean & $\begin{array}{l}\text { Standard } \\
\text { deviation }\end{array}$ & $P$-value & Mean & $\begin{array}{l}\text { Standard } \\
\text { deviation }\end{array}$ & $P$-value & Mean & $\begin{array}{l}\text { Standard } \\
\text { deviation }\end{array}$ & $P$-value & Mean & $\begin{array}{l}\text { Standard } \\
\text { deviation }\end{array}$ & $P$-value \\
\hline \multicolumn{17}{|c|}{ Gender $(N$ total $=344)$} \\
\hline Female & $17 \mid$ & 10213 & 6514 & $<0.001^{\mathrm{a}}$ & 82.04 & 30.56 & $<0.001^{\mathrm{a}}$ & 12.94 & 23.46 & $0.106^{\mathrm{a}}$ & 4.41 & 3.51 & $0.128^{\mathrm{a}}$ & 27.45 & 6.05 & $0.745^{\mathrm{a}}$ \\
\hline Male & 173 & 7037 & 5107 & & 104.15 & 36.83 & & 17.07 & 23.82 & & 5.01 & 3.82 & & 27.64 & 4.64 & \\
\hline \multicolumn{17}{|c|}{ Age groups $(N$ total $=344)$} \\
\hline $31-50$ & 13 & 6668 & 5822 & & 99.76 & 41.46 & & 24.18 & 32.41 & & 4.26 & 2.96 & & 28.87 & 6.03 & \\
\hline $51-60$ & 28 & 6989 & 4474 & $0.003^{b}$ & 96.9 & 28.78 & $0.076^{b}$ & 17.7 & 20.69 & $0.612^{b}$ & 4.27 & 3.68 & $0.444^{b}$ & 29.36 & 4.12 & $0.003^{b}$ \\
\hline $61-70$ & 102 & 7812 & 5739 & $0.005^{c}$ & 99.35 & 31.06 & $0.095^{c}$ & 14.45 & 21.99 & $0.108^{c}$ & 4.35 & 3.39 & $0.231^{c}$ & 28.57 & 6.07 & $0.012^{c}$ \\
\hline $71-80$ & 146 & $867 \mid$ & 5486 & & 91.21 & 36.09 & & 4.77 & 24.94 & & 4.81 & 3.84 & & 27.2 & 5.13 & \\
\hline $81-91$ & 55 & 11250 & 7884 & & 83.39 & 41.76 & & 13.2 & 22.74 & & 5.42 & 3.88 & & 25.44 & 4.33 & \\
\hline \multicolumn{17}{|c|}{ AJCC $(N$ total $=343)$} \\
\hline I & 69 & 9965 & 6382 & & 94.96 & 37.14 & & 13 & 16.35 & & 4.83 & 3.24 & & 27.37 & 7.36 & \\
\hline$\| A$ & 115 & 8588 & 5922 & & 93.16 & 37.25 & & $|4.4|$ & 21.69 & & 4.39 & 3.47 & & 27.92 & 4.64 & \\
\hline$\| B$ & 29 & 7289 & 5097 & $0.148^{b}$ & $102.9 \mid$ & 31.73 & $0.699^{b}$ & 19.57 & 30.36 & $0.873^{b}$ & 5.98 & 4.38 & $0.586^{b}$ & 27.71 & 5.48 & $0.956^{b}$ \\
\hline IIIA & 9 & 6945 & 6117 & $0.082^{c}$ & 86.4 & 19.76 & $0.208^{c}$ & 13.1 & 18.17 & $0.93^{c}$ & 4.06 & 3.12 & $0.775^{c}$ & 26.7 & 4.68 & $0.892^{c}$ \\
\hline IIIB & 71 & 8322 & 5607 & & 90.72 & 33.58 & & 17.3 & 30.78 & & 4.7 & 3.84 & & 27.28 & 5.19 & \\
\hline$I I I C$ & 36 & 9338 & 7687 & & 92.93 & 37.94 & & 14.18 & 23.55 & & 4.71 & 4.32 & & 27.04 & 3.84 & \\
\hline IV & 14 & 5672 & 3448 & & 84.42 & 33.62 & & 13.22 & 19.87 & & 4.7 & 3.69 & & 28.35 & 5.29 & \\
\hline \multicolumn{17}{|c|}{$T$ stage $(N$ total $=342)$} \\
\hline TI & 28 & 9455 & 6342 & & 94.68 & 35.45 & & 17.08 & $|7.8|$ & & 5.43 & 3.83 & & 28.3 & 5.49 & \\
\hline $\mathrm{T} 2$ & 59 & 8927 & 6292 & $0.811^{b}$ & 93.52 & 35.73 & $0.989^{b}$ & 11.16 & 16.02 & $0.534^{\mathrm{b}}$ & 4.35 & 2.77 & $0.654^{b}$ & 27.05 & 7.71 & $0.443^{b}$ \\
\hline T3 & 182 & 8583 & 6091 & $0.336^{c}$ & 92.79 & 36.14 & $0.735^{c}$ & 15.36 & 24.51 & $0.842^{c}$ & 4.73 & 3.81 & $0.463^{c}$ & 27.9 & 4.7 & $0.374^{c}$ \\
\hline T4 & 73 & 8243 & 5791 & & 92.18 & 34.01 & & 16.77 & 28.75 & & 4.69 & 3.99 & & 26.89 & 4.84 & \\
\hline \multicolumn{17}{|c|}{$N$ stage $(N$ total $=337)$} \\
\hline NO & 214 & 8918 & 5997 & $0.449^{b}$ & 94.63 & 36.66 & $0.577^{b}$ & 14.62 & 21.52 & $0.703^{b}$ & 4.74 & 3.56 & $0.985^{b}$ & 27.73 & 5.75 & $0.736^{b}$ \\
\hline NI & 79 & 7907 & 5467 & $0.82^{c}$ & 90 & 32.53 & $0.577^{c}$ & 16.84 & 30 & $0.776^{c}$ & 4.66 & 3.9 & $0.925^{c}$ & 27.29 & 5.32 & $0.539^{c}$ \\
\hline N2 & 44 & 8666 & 7258 & & 91.34 & 35.39 & & 13.47 & 21.75 & & 4.68 & 4.07 & & 27.16 & 3.77 & \\
\hline \multicolumn{17}{|c|}{ Grade $(N$ total $=245)$} \\
\hline 1 & 8 & 10699 & 8464 & $0.563^{b}$ & 89.7 & 25.03 & $0.207^{b}$ & 10.39 & 13.76 & $0.231^{b}$ & 3.62 & 2.14 & $0.463^{b}$ & 23.97 & 5.18 & $0.07 I^{b}$ \\
\hline 2 & 176 & 9105 & 5645 & $0.998^{c}$ & 96.81 & 36.67 & $0.812^{c}$ & 17.11 & 26.21 & $0.691^{c}$ & 4.92 & 3.94 & $0.394^{c}$ & 27.73 & 5.6 & $0.249^{c}$ \\
\hline 3 & 58 & 8670 & 5676 & & 87.13 & 39.43 & & 11.57 & 14.86 & & 4.57 & 2.95 & & 26.84 & 4.33 & \\
\hline \multicolumn{17}{|c|}{ Lymph/vascular invasion (N total $=337$ ) } \\
\hline No & 236 & 8724 & 6099 & $0.938^{\mathrm{a}}$ & 94.21 & 34.52 & $0.373^{\mathrm{a}}$ & 14.08 & 21.87 & $0.505^{\mathrm{a}}$ & 4.69 & 3.54 & $0.977^{\mathrm{a}}$ & 27.56 & 5.55 & $0.71^{\mathrm{a}}$ \\
\hline Yes & $10 \mid$ & 8668 & 6048 & & 90.44 & 37.71 & & 15.92 & 26 & & 4.68 & 3.96 & & 27.31 & 4.95 & \\
\hline \multicolumn{17}{|c|}{ Perineural invasion $(N$ total $=159)$} \\
\hline No & 135 & 7023 & 5870 & $0.027^{\mathrm{a}}$ & 94.69 & 32.84 & $0.609^{\mathrm{a}}$ & 13.05 & 22.93 & $0.94^{\mathrm{a}}$ & 4.18 & 3.34 & $0.928^{\mathrm{a}}$ & 28.06 & 5.44 & $0.887^{\mathrm{a}}$ \\
\hline Yes & 17 & 5099 & 2755 & & 90.37 & 32.46 & & $|2.6|$ & 18.35 & & 4.1 & 2.59 & & 27.85 & 6.76 & \\
\hline \multicolumn{17}{|c|}{ Necrosis $(N$ total $=180)$} \\
\hline No & 142 & 9645 & 5574 & $0.351^{\mathrm{a}}$ & 94.38 & 38.89 & $0.77^{\mathrm{a}}$ & 16.26 & 22.53 & $0.915^{\mathrm{a}}$ & 5.08 & 3.91 & $0.81^{a}$ & 27.64 & 4.82 & $0.918^{\mathrm{a}}$ \\
\hline Yes & 38 & 8707 & 5152 & & 92.34 & 34.39 & & $|5.8|$ & 27.05 & & 4.91 & 4.19 & & 27.54 & 5.81 & \\
\hline \multicolumn{17}{|c|}{ Lymphocytic infiltrate ( $N$ total $=267$ ) } \\
\hline No & 92 & 7527 & 4346 & & 95.01 & 37.05 & $0.617^{b}$ & 14.06 & 25.53 & $0.62^{b}$ & 4.03 & 3.13 & $0.234^{b}$ & 27.46 & 4.7 & \\
\hline । & 112 & 9838 & 5737 & $0.014^{b}$ & 91.17 & 33.96 & $0.923^{c}$ & 16.37 & 24.45 & $0.605^{c}$ & 5.06 & 3.93 & $0.907^{c}$ & 27.27 & 5.85 & $0.928^{b}$ \\
\hline 2 & 49 & 9638 & 6135 & $0.074^{c}$ & 87.69 & 33.65 & & 18.19 & 26.79 & & 4.72 & 3.82 & & 27.05 & 4.94 & $0.521^{c}$ \\
\hline 3 & 14 & 10497 & 8107 & & 97.15 & 32.16 & & 9.67 & 16.24 & & 4.27 & 3.26 & & 26.46 & 5.43 & \\
\hline
\end{tabular}

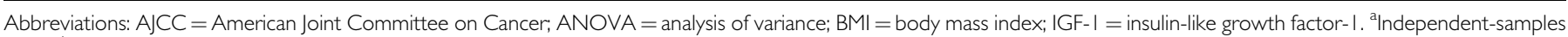
t-test. ${ }^{b}$ One-way ANOVA. 'Test for linear trend.

$P<0.001)$, and negatively correlated with serum levels of adiponectin $(r=-0.32, P<0.001)$ (Table 3). Insulin showed a positive correlation with C-peptide $(r=0.63, P<0.001)$, as expected, and IGF-1 was correlated with both insulin $(r=0.14$, $P=0.01)$ and C-peptide $(r=0.14, P=0.01)$. Serum adiponectin showed an inverse correlation with IGF-1, insulin and C-peptide $(r=-0.21, P<0.001 ; r=-0.018, P=0.001 ; r=-0.014, P=0.01$, respectively).

\section{Obesity, inflammation and angiogenic factors}

Serum levels of the angiogenic proteins, Ang-2 and VEGF-A, were correlated $(r=0.19, P<0.001)$ (Table 3$)$. There was a positive correlation between serum CRP and both VEGF-A $(r=0.23$, $P<0.0001)$ and Ang-2 $(r=0.43, P<0.001)$. Serum levels of Ang-2 and C-peptide were positively correlated $(r=0.14, P=0.007)$. Serum VEGF-A was positively correlated with IGF-1 in males $(r=0.25, P=0.001)$, and a similar trend was observed for the whole cohort $(r=0.10, P=0.066$; Table 3$)$. Serum CRP levels showed a negative association with IGF-1 $(r=-0.18, P=0.001)$. Neither VEGF-A nor Ang-2 was associated with BMI or serum adiponectin levels $(P>0.05)$.

\section{Survival analysis}

During the 10 years of follow-up time, 91 patients died from all causes in the study cohort, with median survival not reached. Eleven of the 14 patients with stage IV disease had died. KaplanMeier survival analysis showed that patients with high serum levels of CRP $(P<0.001 ; P=0.01$ excluding stage IV $)$ and Ang-2 
Table 3 Associations of angiogenic, inflammation and obesity-related factors in colorectal cancer patients

\begin{tabular}{|c|c|c|c|c|c|c|c|}
\hline & $\begin{array}{l}\text { VEGF-A } \\
(N=344)\end{array}$ & $\begin{array}{c}\text { Ang-2 } \\
(N=344)\end{array}$ & $\begin{array}{l}\text { Adiponectin } \\
(N=344)\end{array}$ & $\begin{array}{c}\text { CRP } \\
(N=344)\end{array}$ & $\begin{array}{c}\text { IGF-I } \\
(N=344)\end{array}$ & $\begin{array}{c}\text { Insulin } \\
(N=344)\end{array}$ & $\begin{array}{l}\text { C-peptide } \\
(N=344)\end{array}$ \\
\hline \multicolumn{8}{|l|}{ Ang-2 $(N=344)$} \\
\hline \multicolumn{8}{|l|}{ Adiponectin $(N=344)$} \\
\hline Pearson's correlation & -0.04 & 0.05 & & & & & \\
\hline \multicolumn{8}{|l|}{$C R P(N=344)$} \\
\hline Pearson's correlation & 0.23 & 0.43 & -0.02 & & & & \\
\hline$P$-value & 0.000 & 0.000 & 0.788 & & & & \\
\hline \multicolumn{8}{|l|}{$|G F-|(N=344)$} \\
\hline Pearson's correlation & 0.10 & -0.01 & -0.21 & -0.18 & & & \\
\hline$P$-value & 0.066 & 0.894 & 0.000 & 0.001 & & & \\
\hline \multicolumn{8}{|l|}{ C-peptide $(\mathrm{N}=344)$} \\
\hline Pearson's correlation & 0.02 & 0.14 & -0.14 & -0.02 & 0.14 & 0.63 & \\
\hline$P$-value & 0.738 & 0.007 & 0.010 & 0.690 & 0.010 & 0.000 & \\
\hline \multicolumn{8}{|l|}{$B M I(N=3 / 8)$} \\
\hline Pearson's correlation & 0.04 & -0.03 & -0.32 & 0.07 & 0.09 & 0.21 & 0.27 \\
\hline$P$-value & 0.448 & 0.542 & 0.000 & 0.241 & 0.105 & 0.000 & 0.000 \\
\hline
\end{tabular}

$(P<0.001 ; P=0.002$, excluding stage IV) had a significantly worse outcome (Figure 1A and B). High serum VEGF-A was also associated with poorer survival $(P=0.053 ; P=0.041$ excluding stage IV) (Figure 1C). As expected, tumour AJCC stage, T stage, $\mathrm{N}$ stage, lymphatic and vascular invasion, and perineural invasion were significantly associated with patient survival $(P<0.01$, data not shown). The BMI did not significantly affect survival $(P=0.35$, data not shown). No association was shown between type 2 diabetes and survival $(n=28, P=0.26)$.

A separate survival analysis was also completed for patients with AJCC stage II cancer (stages IIA and IIB). The CRP remained a significant predictor of outcome within this group $(P=0.04$, Figure 1D), whereas Ang-2, $\mathrm{T}$ stage, lymphatic and vascular invasion, and perineural invasion were not significant predictors of survival in this sub-cohort (data not shown).

Cox regression analysis of individual predictors showed that VEGF-A, Ang-2 and CRP were significant predictors of overall survival for the whole cohort $(P<0.001$; Table 4$)$. These three predictors were further analysed together in a multivariable model, in which VEGF-A and Ang-2 remained significant predictors, whereas CRP was not significant (Table 4, model 1). After adjusting for tumour stage and age, both VEGF-A and CRP lost their predictive value and Ang-2 remained the only significant predictor of survival (Table 4 , model 2 ).

\section{DISCUSSION}

This study demonstrated strong associations of markers of angiogenesis and inflammation with cancer progression and patient survival in a cohort of 344 colorectal cancer patients. Serum levels of Ang- 2 emerged as strongly predictive of overall survival in our multivariable survival analysis. Angiopoietin-2 regulates tumour angiogenesis (Ahmad et al, 2001a, b; Sarraf-Yazdi et al, 2008), and increased levels of tumour Ang-2 are associated with more aggressive, angiogenic CRC tumours (Chung et al, 2006). The positive correlations observed between serum Ang-2 and serum C-peptide (a stable marker of circulating insulin levels), and between VEGF-A and IGF-1 in males, may implicate insulin and IGF-1 in promoting a systemic pro-angiogenic environment, and potentially increasing tumour angiogenesis.

Prevalence of insulin resistance and type 2 diabetes varies markedly by age, as well as ethnicity. In individuals aged $>60$ years, the prevalence of diagnosed diabetes in New Zealand is $9.5 \%$ for Europeans, and $21.0 \%$ and $24.5 \%$ for Māori and Pacific Island people, respectively (Ministry of Health, 2007). The ethnic breakdown of this clinical cohort reflects that of the Canterbury background population, which is predominantly European (77.4\% European, 7.2\% Māori) (Morrin et al, 2005; Census, 2006). The prevalence of diagnosed type 2 diabetes was $8.1 \%$ in this colorectal cancer cohort, reflecting that of the background population. Our study did not find a direct relationship between type 2 diabetes and colorectal cancer, but the total number with diabetes was relatively small.

It is now well established that obesity is characterised by chronic inflammation (Greenberg and Obin, 2006; Park et al, 2010), with associated increases of CRP, interleukin-6 (IL-6) and plasminogen activator inhibitor (Dandona et al, 2004). Recent in vivo data in dietary and genetically obese mouse models demonstrated obesityrelated liver inflammation and subsequent release of IL-6 and TNF $\alpha$ (Park et al, 2010). Our clinical data supports a significant association between Ang- 2 and inflammation, via the acute phase inflammatory protein, CRP. This association is supported by in vitro data (Bello et al, 2008; Turu et al, 2008; Porta et al, 2009) and recent data from an Ang-2 knock-out mouse model, where lack of Ang-2 reduced inflammatory bowel disease (Ganta et al, 2010). However, CRP may also mediate inhibition of angiogenesis, as shown in vitro (Yang et al, 2005). Our clinical findings suggest that the influence of inflammation on colorectal cancer progression and outcome may involve Ang-2-mediated pathways. To support these 

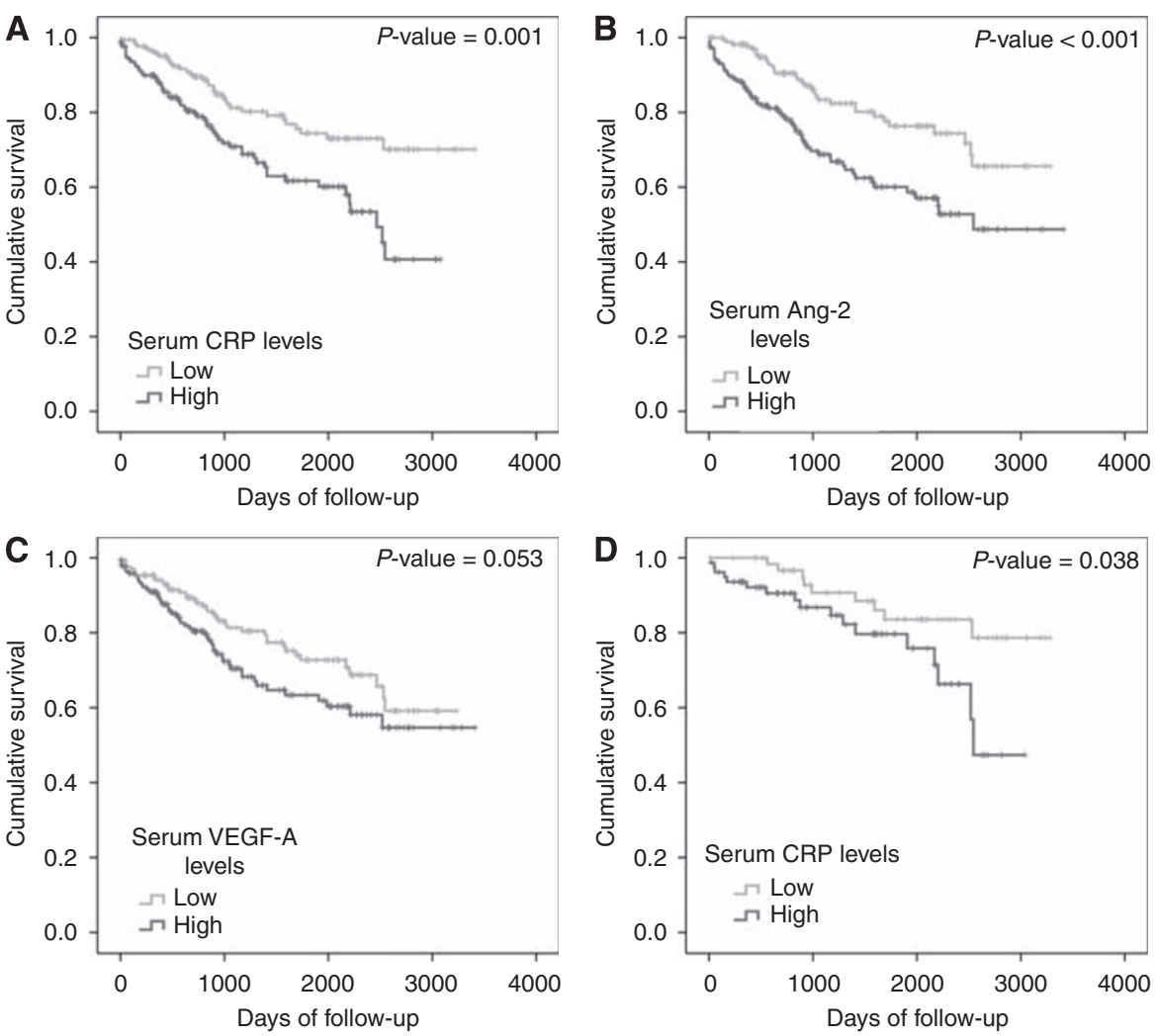

Figure I Survival of colorectal cancer patients from surgery to death from any cause by Kaplan-Meier survival analysis. Survival between groups with high and low serum (A) CRP, (B) Ang-2 and (C) VEGF-A. (D) Survival of patients with AJCC stage II disease between groups with high and low serum CRP. Median values were used as cut points for high vs low values.

observations, markers of angiogenesis are being investigated in tumour samples from this patient cohort.

In our study, serum levels of Ang-2 were a stronger predictor of survival than serum levels of VEGF-A, the principal angiogenic factor associated with poor outcome in colorectal cancer (Cao et al, 2009). Circulating levels of Ang-2 have been shown to correlate with poor patient survival in other cancers including melanoma and lung cancer (Park et al, 2007; Helfrich et al, 2009), and patients with metastatic colorectal cancer have higher levels of serum Ang-2 than healthy controls (Goede et al, 2010). Angiopoietin-2 regulates vascular remodelling and endothelial responsiveness to pro-inflammatory cytokines (Fiedler et al, 2006). In addition, recent in vitro and in vivo studies have demonstrated that Ang-2 acts as a chemoattractant for pro-angiogenic Tie2expressing monocyte/macrophages (TEM), and stimulates TEM to express tumour-promoting factors. Mice with Ang-2 overexpressed in tumour vasculature had high serum Ang-2 levels, increased TEM infiltration of tumours and an increased number of tumour microvessels with immature phenotype (Murdoch et al, 2007; Coffelt et al, 2010). Thus, high levels of Ang-2 may impact patient survival by facilitating tumour vascular disruption, and by skewing tumour-infiltrating leukocytes towards an alternatively activated (M2) phenotype that promotes tumour angiogenesis and progression.

Experimental and epidemiological studies support the concept that chronic inflammation has cancer-promoting properties (Mantovani et al, 2008; Porta et al, 2009). In our study, elevated serum CRP levels were positively associated with markers of more advanced disease and worse overall patient survival, consistent with other studies (Nozoe et al, 1998, 2008). In these studies, CRP levels above the upper limit of normal of $5 \mathrm{mgl}^{-1}$ (Nozoe et al, 2008) or $8 \mathrm{mgl}^{-1}$ (Nozoe et al, 1998) were considered elevated. However, in cardiovascular disease, CRP is an established risk factor at levels as low as $0.49 \mathrm{mgl}^{-1}$ (Ridker et al, 2002), and no such threshold has yet been determined for cancer. Therefore, in our study, CRP levels were treated as a continuous variable, and median $\left(4.1 \mathrm{mgl}^{-1}\right)$ was used as a cut point between low and high levels of CRP.

The CRP was the only significant predictor of overall survival in our sub-cohort of 144 AJCC stage II patients in a multivariable analysis. While clinical factors are currently used to identify stage II patients who have a poor prognosis and hence require adjuvant chemotherapy, a predictive serum biomarker would be of direct clinical utility. Although Nozoe et al (2008) reported CRP to be prognostic in a group of 116 patients with all Dukes stages, only 34 had Dukes B disease. Our data suggest that CRP could be used to support decisions about adjuvant chemotherapy, but would need further testing in stage II patients.

Associations between CRP and other surrogate markers of obesity were not significant in this study, although this link is supported in the literature (Koukourakis et al, 2009; Nguyen et al, 2009). A limitation of our study may be the decision to measure CRP at diagnosis, which may have obscured the contribution from obesity, as inflammation within the primary tumour may have been the main contributor to high serum CRP. This is supported by the increase in CRP with T stage. A large study in healthy adults across the weight spectrum in the United States, found a direct correlation between serum CRP levels and increasing BMI (Nguyen et al, 2009). A similar correlation was observed in cancer patients with no detectable tumour, but was lost in cancer patients with evident cancer burden (Koukourakis et al, 2009). Together with our data, this suggests that CRP from inflammation in advanced cancer may obscure that from obesity-related inflammation.

None of the markers of obesity (BMI and serum markers) showed an association with tumour progression or patient survival, for the whole cohort, or by gender. The relationship 
Table 4 Cox regression survival analyses

\begin{tabular}{|c|c|c|c|}
\hline & Hazard ratio ${ }^{a}$ & $95 \% \mathrm{Cl}$ & Total P-value \\
\hline \multicolumn{4}{|l|}{ Individual predictors } \\
\hline VEGF-A & 1.09 & $(1.04-1.15)$ & $<0.001$ \\
\hline Ang-2 & 1.27 & $(1.13-1.42)$ & $<0.001$ \\
\hline CRP & 1.13 & $(1.06-1.21)$ & $<0.001$ \\
\hline Age & 1.37 & $(1.08-1.75)$ & 0.010 \\
\hline Insulin & 1.00 & $(0.99-1.01)$ & 0.924 \\
\hline C-peptide & 1.02 & $(0.96-1.07)$ & 0.590 \\
\hline Adiponectin & 1.00 & $(0.97-1.04)$ & 0.937 \\
\hline IGF-I & 1.00 & $(0.94-1.06)$ & 0.982 \\
\hline \multicolumn{4}{|l|}{ BMl groups: } \\
\hline Underweight & 1.94 & $(0.59-6.45)$ & \multirow{4}{*}{0.371} \\
\hline Normal & 1.00 & & \\
\hline Overweight & 0.81 & $(0.49-1.35)$ & \\
\hline Obese & 0.74 & $(0.40-1.33)$ & \\
\hline \multicolumn{4}{|l|}{ AJCC stages: } \\
\hline Stage I & 1.00 & & \multirow{4}{*}{$<0.001$} \\
\hline Stage II & 1.41 & $(0.64-3.12)$ & \\
\hline Stage III & 4.56 & $(2.15-9.68)$ & \\
\hline Stage IV & 15.29 & $(6.10-38.38)$ & \\
\hline \multicolumn{4}{|c|}{ Multivariable model I } \\
\hline VEGF-A & 1.07 & $(1.01-1.12)$ & 0.018 \\
\hline Ang-2 & 1.17 & $(1.02-1.34)$ & 0.024 \\
\hline CRP & 1.07 & $(0.10-1.15)$ & 0.067 \\
\hline \multicolumn{4}{|c|}{ Multivariable model 2} \\
\hline \multicolumn{4}{|c|}{ A/CC stages: } \\
\hline Stage I & 1.00 & & \multirow{4}{*}{$<0.001$} \\
\hline Stage II & 1.40 & $(0.62-3.14)$ & \\
\hline Stage III & 4.30 & $(1.99-9.29)$ & \\
\hline Stage IV & 17.57 & $(6.53-47.28)$ & \\
\hline Age & 1.41 & $(1.10-1.80)$ & 0.006 \\
\hline VEGF-A & 1.04 & $(0.99-1.09)$ & 0.136 \\
\hline Ang-2 & 1.23 & $(1.06-1.42)$ & 0.006 \\
\hline CRP & 1.00 & $(0.93-1.09)$ & 0.956 \\
\hline
\end{tabular}

Abbreviations: $\mathrm{AJCC}=$ American Joint Committee on Cancer, Ang-2 = angiopoietin-2; $\mathrm{BMI}=$ body mass index; $\mathrm{Cl}=$ confidence interval; $\mathrm{CRP}=\mathrm{C}$-reactive protein; IGF-I = insulin-like growth factor-I; VEGF-A = vascular endothelial growth factor-A. ${ }^{a}$ Change in Hazard ratio for continuous variables was estimated using the following units: I00 units VEGF-I, 1000 units Ang-2, I unit CRP, insulin and C-peptide, 10 units IGF-I and per decade of age.

between obesity and patient survival remains equivocal. In a study of over 4000 colorectal cancer patients, morbidly obese patients were $40 \%$ more likely to have a recurrence or secondary tumour, and $30 \%$ more likely to die, compared with patients with normal BMI (Dignam et al, 2006). In contrast, a similar sized study showed no difference in overall, disease-free (DFS) or recurrentfree survival across all BMI groups (Meyerhardt et al, 2003), except that obese women younger than 50 years of age had a worse outcome compared with women with normal BMI. Our cohort were an older population, with $96 \%$ of patients over 50 years of age

\section{REFERENCES}

Ahmad SA, Liu W, Jung YD, Fan F, Reinmuth N, Bucana CD, Ellis LM (2001a) Differential expression of angiopoietin-1 and angiopoietin-2 in colon carcinoma. A possible mechanism for the initiation of angiogenesis. Cancer 92: $1138-1143$

Ahmad SA, Liu W, Jung YD, Fan F, Wilson M, Reinmuth N, Shaheen RM, Bucana CD, Ellis LM (2001b) The effect of angiopoietin-1 and -2 on tumor growth and angiogenesis in human colon cancer. Cancer Res 61: 1255-1259

Bello G, Cailotto F, Hanriot D, Kolopp-Sarda MN, Latger-Cannard V, Hess K, Zannad F, Longrois D, Ropars A (2008) C-reactive protein (CRP) increases VEGF-A expression in monocytic cells via a and only six women $<50$ years old. Our study did not determine waist circumference, and a recent, smaller study (Haydon et al, 2006) found that waist circumference, but not BMI, was associated with survival. A subsequent study by Meyerhardt found that morbidly obese patients had decreased DFS, but not overall survival (Meyerhardt et al, 2008). Only $6.9 \%$ of patients in our study were morbidly obese, and they could not be analysed separately. The distribution of BMI categories in our study $(25.1 \%$ $>$ BMI 30) compared well with other studies $(17.5-34.0 \%>30$ BMI) (Dignam et al, 2006; Reeves et al, 2007; Meyerhardt et al, 2008). Hence, current data suggest that severe obesity, rather than a continuum of BMI, impacts negatively on survival from colorectal cancer.

Owing to the proven unreliability of BMI as a marker of obesity, our study sought to define surrogate serum markers of obesity. While total serum levels of adiponectin and IGF-1 were measured, our assay system was unable to distinguish high molecular weight multimers of adiponectin, which represent the most biologically active form (Kadowaki et al, 2006), and may have better predictive value. In addition, the IGF-binding proteins, which regulate bioavailable levels of IGF-1 in circulation (Fuchs et al, 2008), were not measured. Despite these limitations, our study demonstrated a consistent and significant relationship among the serum markers of obesity measured (insulin, C-peptide, IGF-1, adiponectin, BMI), supporting the conclusion of a limited relationship between obesity and colorectal cancer survival. We, therefore, propose that the influence of obesity on tumour progression and survival in colorectal cancer may be due to obesity-related inflammation, rather than factors associated with obesity per se.

We have reported serum markers of obesity, inflammation and angiogenesis at diagnosis of colorectal cancer, and correlated them with clinicopathological variables and with outcome. We did not confirm a worse outcome from diagnosis for obese patients, or for type 2 diabetes, although this conclusion may be limited by small numbers. Highly sensitive CRP, a marker of inflammation, was associated with survival, increased with tumour stage and may have reflected inflammation in the tumour as well as that due to obesity. We have established the value of the pro-angiogenic factor Ang-2 in serum to predict survival. We have shown an association between obesity, inflammation, angiogenesis and outcome, but not demonstrated a role of the insulin-IGF-1 axis. However, the possible effects of obesity and insulin-IGF-1 on response to chemotherapy treatment warrant further study.

\section{ACKNOWLEDGEMENTS}

We thank the following funding agencies for their support: Top Achiever Doctoral Scholarship from the Tertiary Education Commission (EV), Cancer Society of New Zealand (GUD, MJC), Genesis Oncology Trust (Bruce Blue Award, GUD), Lottery Health New Zealand (MJC) and University of Otago (MJC). We thank the Cancer Society Tissue Bank, Christchurch for samples.
PI3-kinase and ERK 1/2 signaling dependent pathway. Atherosclerosis 200: $286-293$

Birmingham JM, Busik JV, Hanses-Smith FM, Fenton JI (2009) Novel mechanism for obesity-induced colon cancer progression. Carcinogenesis 30: $690-697$

Cao D, Hou M, Guan YS, Jiang M, Yang Y, Gou HF (2009) Expression of HIF-1alpha and VEGF in colorectal cancer: association with clinical outcomes and prognostic implications. BMC Cancer 9: 432

Center MM, Jemal A, Smith RA, Ward E (2009) Worldwide variations in colorectal cancer. CA Cancer J Clin 59: 366-378 
Census (2006) QuickStats about Canterbury region, http://www.stats. govt.nz/Census/2006CensusHomePage/QuickStats/AboutAPlace/SnapShot. aspx? type $=$ region $\&$ ParentID $=\&$ tab $=$ Culturaldiversity\&id $=1000013$, accessed 21 April 2010

Chung YC, Hou YC, Chang CN, Hseu TH (2006) Expression and prognostic significance of angiopoietin in colorectal carcinoma. J Surg Oncol 94: $631-638$

Coffelt SB, Tal AO, Scholz A, De Palma M, Patel S, Urbich C, Biswas SK, Murdoch C, Plate KH, Reiss Y, Lewis CE, Coffelt SB, Tal AO, Scholz A, De Palma M, Patel S, Urbich C, Biswas SK, Murdoch C, Plate KH, Reiss Y, Lewis CE (2010) Angiopoietin-2 regulates gene expression in TIE2expressing monocytes and augments their inherent proangiogenic functions. Cancer Res 70: 5270-5280

Dandona P, Aljada A, Bandyopadhyay A (2004) Inflammation: the link between insulin resistance, obesity and diabetes. Trends Immunol 25: 4-7

Dignam JJ, Polite BN, Yothers G, Raich P, Colangelo L, O'Connell MJ, Wolmark N (2006) Body mass index and outcomes in patients who receive adjuvant chemotherapy for colon cancer. J Natl Cancer Inst 98: 1647-1654

Fiedler U, Reiss Y, Scharpfenecker M, Grunow V, Koidl S, Thurston G, Gale NW, Witzenrath M, Rosseau S, Suttorp N, Sobke A, Herrmann M, Preissner KT, Vajkoczy P, Augustin HG (2006) Angiopoietin-2 sensitizes endothelial cells to TNF-alpha and has a crucial role in the induction of inflammation. Nat Med 12: 235-239

Frizelle F (2009) Cancer in New Zealand. N Z Med J 122: 7-9

Fuchs CS, Goldberg RM, Sargent DJ, Meyerhardt JA, Wolpin BM, Green EM, Pitot HC, Pollak M (2008) Plasma insulin-like growth factors, insulin-like binding protein-3, and outcome in metastatic colorectal cancer: results from intergroup trial N9741. Clin Cancer Res 14: $8263-8268$

Ganta VC, Cromer W, Maills GL, Traylor J, Jennings M, Daley S, Clark B, Mathis JM, Bernas M, Boktor M, Jordan P, Witte M, Alexander JS (2010) Angiopoietin-2 in experimental colitis. Inflamm Bowel Dis 16: $1029-1039$

Giovannucci E (2007) Metabolic syndrome, hyperinsulinemia, and colon cancer: a review. Am J Clin Nutr 86: 836-842

Goede V, Coutelle O, Neuneier J, Reinacher-Schick A, Schnell R, Koslowsky TC, Weihrauch MR, Cremer B, Kashkar H, Odenthal M, Augustin HG, Schmiegel W, Hallek M, Hacker UT (2010) Identification of serum angiopoietin-2 as a biomarker for clinical outcome of colorectal cancer patients treated with bevacizumab-containing therapy. Br J Cancer 103: $1407-1414$

Gonullu G, Kahraman H, Bedir A, Bektas A, Yücel I (2009) Association between adiponectin, resistin, insulin resistance, and colorectal tumors. Int J Colorectal Dis 25: 205-212

Greenberg AS, Obin MS (2006) Obesity and the role of adipose tissue in inflammation and metabolism. Am J Clin Nutr 83: 461-465

Greene FL, Page DL, Fleming ID, Fritz AG, Balch CM, Haller DG, Morrow M (eds). (2002) AJCC Cancer Staging Manual, 6th edn, Lippincott Raven Publishers: Philadelphia

Haydon AMM, MacInnis RJ, English DR, Giles GG (2006) Effect of physical activity and body size on survival after diagnosis with colorectal cancer. Gut 55: 62-67

Helfrich I, Edler L, Sucker A, Thomas M, Christian S, Schadendorf D, Augustin HG (2009) Angiopoietin-2 levels are associated with disease progression in metastatic malignant melanoma. Clin Cancer Res 15: $1384-1392$

Kadowaki T, Yamauchi T, Kubota N, Hara K, Ueki K, Tobe K (2006) Adiponectin and adiponectin receptors in insulin resistance, diabetes, and the metabolic syndrome. J Clin Invest 116: 1784-1792

Komninou D, Ayonote A, Richie JP, Rigas B (2003) Insulin resistance and its contribution to colon carcinogenesis. Exp Biol Med 228: 396-405

Koukourakis MI, Kambouromiti G, Pitsiava D, Tsousou P, Tsiarkatsi M, Kartalis G (2009) Serum C-reactive protein (CRP) levels in cancer patients are linked with tumor burden and are reduced by antihypertensive medication. Inflammation 32: 169-175

Litton JK, Gonzalez-Angulo AM, Warneke CL, Buzdar AU, Kau S-W, Bondy M, Mahabir S, Hortobagyi GN, Brewster AM (2008) Relationship between obesity and pathologic response to neoadjuvant chemotherapy among women with operable breast cancer. J Clin Oncol 26: 4072-4077

Mantovani A, Allavena P, Sica A, Balkwill F (2008) Cancer-related inflammation. Nature 454: 436-444

Merkow RP, Bilimoria KY, Cohen ME, Richards K, Ko CY, Hall BL (2009) Variability in reoperation rates at 182 hospitals: a potential target for quality improvement. J Am Coll Surg 209: 557-564
Meyerhardt JA, Catalano PJ, Haller DG, Mayer RJ, Benson III AB, Macdonald JS, Fuchs CS (2003) Influence of body mass index on outcomes and treatment-related toxicity in patients with colon carcinoma. Cancer 98: 484-495

Meyerhardt JA, Niedzwiecki D, Hollis D, Saltz LB, Mayer RJ, Nelson H, Whittom R, Hantel A, Thomas J, Fuchs CS (2008) Impact of body mass index and weight change after treatment on cancer recurrence and survival in patients with stage III colon cancer: findings from cancer and leukemia group B 89803. J Clin Oncol 26: 4109-4115

Ministry of Health (2007) Diabetes surveillance: population-based estimates and projections for New Zealand, 2001-2011: Public Health Intelligence Occasional Bulletin No. 46. Ministry of Health: Wellington. http://www.moh.govt.nz/moh.nsf/indexmh/diabetes-suveillance-populationestimates-projections-2001-2011, accessed 21 April 2010

Ministry of Health (2008) A Portrait of Health. Key Results of the 2006/07 New Zealand Health Survey. Ministry of Health: Wellington

Moghaddam AA, Woodward M, Huxley R (2007) Obesity and risk of colorectal cancer: a meta-analysis of 31 studies with 70000 events. Cancer Epidemiol Biomarkers Prev 16: 2533-2547

Moon HG, Ju YT, Jeong CY, Jung EJ, Lee YJ, Hong SC, Ha WS, Park ST, Choi SK (2008) Visceral obesity may affect oncologic outcome in patients with colorectal cancer. Ann Surg Oncol 15: 1918-1922

Morrin H, Gunningham S, Currie M, Dachs G, Fox S, Robinson B (2005) The Christchurch Tissue Bank to support cancer research. NZ Med J 118: U1735

Murdoch C, Tazzyman S, Webster S, Lewis CE (2007) Expression of Tie-2 by human monocytes and their responses to angiopoietin-2. J Immunol 178: $7405-7411$

Nguyen XM, Lane J, Smith BR, Nguyen NT (2009) Changes in inflammatory biomarkers across weight classes in a representative US population: a link between obesity and inflammation. J Gastrointest Surg 13: $1205-1212$

Nozoe T, Matsumata T, Kitamura M, Sugimachi K (1998) Significance of preoperative elevation of serum C-reactive protein as an indicator for prognosis in colorectal cancer. Am J Surg 176: 335-338

Nozoe T, Mori E, Takahashi I, Ezaki T (2008) Preoperative elevation of serum C-reactive protein as an independent prognostic indicator of colorectal carcinoma. Surg Today 38: 597-602

Pais R, Silaghi H, Silaghi AC, Rusu ML, Dumitrascu DL (2009) Metabolic syndrome and risk of subsequent colorectal cancer. World J Gastroenterol 15: $5141-5148$

Park EJ, Lee JH, Yu G-Y, He G, Ali SR, Holzer RG, Osterreicher $\mathrm{CH}$ Takahashi H, Karin M (2010) Dietary and genetic obesity promote liver inflammation and tumorigenesis by enhancing IL- 6 and TNF expression. Cell 140: $197-208$

Park JH, Park KJ, Kim YS, Sheen SS, Lee KS, Lee HN, Oh YJ, Hwang SC (2007) Serum angiopoietin-2 as a clinical marker for lung cancer. Chest 132: $200-206$

Parkin DM, Bray F, Ferlay J, Pisani P (2005) Global cancer statistics, 2002 CA Cancer J Clin 55: 74-108

Porta C, Larghi P, Rimoldi M, Grazia Totaro M, Allavena P, Mantovani A, Sica A (2009) Cellular and molecular pathways linking inflammation and cancer. Immunobiology 214: 761-777

Reeves GK, Pirie K, Beral V, Green J, Spencer E, Bull D (2007) Cancer incidence and mortality in relation to body mass index in the Million Women Study: cohort study. BMJ 335: 1-11

Reinmuth N, Fan F, Liu W, Parikh AA, Stoeltzing O, Jung YD, Bucana CD, Radinsky R, Gallick GE, Ellis LM (2002) Impact of insulin-like growth factor receptor-I function on angiogenesis, growth, and metastasis of colon cancer. Lab Invest 82: 1377-1389

Ridker PM, Rifai N, Rose L, Buring JE, Cook NR (2002) Comparison of C-reactive protein and low-density lipoprotein cholesterol levels in the prediction of first cardiovascular events. $N$ Engl J Med 347: $1557-1565$

Rmali KA, Puntis MCA, Jiang WG (2006) Tumour-associated angiogenesis in human colorectal cancer. Colorectal Dis 9: 3-14

Sandhu MS, Dunger DB, Giovannucci EL (2002) Insulin, insulin-like growth factor-1 (IGF-1), IGF binding proteins, their biologic interactions, and colorectal cancer. J Natl Cancer Inst 94: $972-980$

Sarraf-Yazdi S, Mi J, Moeller BJ, Niu X, White RR, Kontos CD, Sullenger BA, Denwhirst MW, Clary BM (2008) Inhibition of in vivo tumour angiogenesis and growth via systemic delivery of angiopoietin 2-specific RNA aptamer. J Surg Res 146: 16-23 
Ang-2 and CRP in colorectal cancer

E Volkova et al

Trevisan M, Liu J, Muti P, Misciagna G, Menotti A, Fucci F (2001) Markers of insulin resistance and colorectal cancer mortality. Cancer Epidemiol Biomarkers Prev 10: 937 -941

Tsujinaka S, Konishi F, Kawamura YJ, Saito M, Tajima N, Tanaka O, Lefor AT (2008) Visceral obesity predicts surgical outcomes after laparoscopic colectomy for sigmoid colon cancer. Dis Colon Rectum 51: $1757-1765$

Turu MM, Slevin M, Matou S, West D, Rodríguez C, Luque A, GrauOlivares M, Badimon L, Martinez-Gonzalez J, Krupinski J (2008) Creactive protein exerts angiogenic effects on vascular endothelial cells and modulates associated signalling pathways and gene expression. $B M C$ Cell Biol 9: 47

Wolpin BM, Meyerhardt JA, Chan AT, Ng K, Chan JA, Wu K, Pollak MN, Giovannucci EL, Fuchs CS (2009) Insulin, the insulin-like growth factor axis, and mortality in patients with nonmetastatic colorectal cancer. $J$ Clin Oncol 27: 176-185

Yang H, Nan B, Yan S, Li M, Yao Q, Chen C (2005) C-reactive protein decreases expression of the VEGF receptors and neuropilins and inhibits VEGF165-induced cell proliferation in human endothelial cells. Biochem Biophys Res Commun 333: $1003-1010$ 